\title{
Ex-combatants at the polls: Exploring focus groups and electoral meaning
}

\author{
By Johanna Söderström (Uppsala University)
}

This paper investigates the meaning attached to elections among ex-combatants in Liberia, in relation to the historic elections of 2005. These elections were generally considered successful, and should therefore be instrumental in the consolidation of democracy; this paper investigates the extent of such consolidation that can be seen in their wake. In particular, the meaning attached to elections is described in terms of voting behaviour and motivation, as well as the application of the equality principle, and finally in relation to the perceived legitimacy of the elections, based on focus group discussions carried out in the spring of 2008 in Liberia. This paper also tries to gauge the advantages and disadvantages of using focus groups as a data collection method. The creation of trust in a well designed focus group, which given the field of research - post-conflict context - may be especially important. The conclusions presented in this paper point to problems vis-à-vis the legitimacy of the elections which may have long term implications for the consolidation of democracy in Liberia. However, other areas, in particular attitudes towards vote buying, show more positive tendencies.

\section{Introduction: Researching electoral meaning}

The elections in Liberia in 2005 were extraordinary. After 14 years of civil war Liberia held elections in October and November, and not only did the Liberian electorate elect the first female president in Africa ever (Ellen Johnson Sirleaf won with 59.4\% of the votes), but the elections were also historic from a national perspective. In several different areas the elections exceeded expectations; they were free and fair $^{l}$ and were more similar to African peacetime polls than post-conflict elections. The elections were also highly competitive yet violence-free (Harris 2006:377f, 393; NDI 2007:29). Given this remarkable assessment, this paper evaluates the perceptions of these elections among the ex-combatant community in Liberia, and discusses their possible impact on the long-term democratisation process.

Did the elections of 2005 provide a gateway to democracy for ex-combatants? Can we see evidence of democratic meaning attached to the ex-combatants' electoral experience? In this paper I argue that the elections in Liberia were to a large part connected democratic issues, but that nonetheless the elections lacked legitimacy for many ex-combatants. Their distrust of the election results and feeling of abandonment by politicians in general are still serious problems. This paper also addresses the appropriateness and difficulties of using focus groups to study this phenomenon.

Elections have come to take on a special, or even inflated, importance in the democracy and democratisation literature (see e.g. Elklit and Svensson 1997:34; Mainwaring 1992:297). Recognizing that elections matter is not the same as reducing democracy to "the regular holding of elections" (Schmitter and Karl 1991:85; Bratton 1998:52). In this paper, elections matter, not just in and of themselves, but as a stepping stone for the development of a democratic culture. Elections contribute to democratisation even if they are flawed (Lindberg 2009), but successful elections should more importantly be able to contribute through 
legitimizing the political system and infusing democratic values among the citizens, i.e. advance the democratisation process (see e.g. Linz and Stepan 1996:15f; cf. Schedler 1998:91, 93, 100).

The political science research community knows very little about the meaning attached to elections in general, and in Africa in particular (Schaffer 1998:23, 88-89, 106-31; Young 1993:307). This paper will begin to rectify this, by examining and describing ex-combatants' understanding and experience of, as well as the meaning they attach to elections. Thus, we will go beyond a mere observer's view of elections, and explore the perception of elections among the citizenry itself, a perspective often ignored in this field (Bratton 1998:62; Mainwaring 1992:302f). If election observers declare an election as free and fair, what does it matter if the electorate themselves cannot relate to such an evaluation? Indeed, this seems to have been the case in Liberia. This entails exploring political culture as a way to take stock of the democratisation process. This paper focuses on one segment of the masses, namely the volatile and potentially problematic ex-combatants. This group is particularly important as they, if they have the inclination, can more forcefully distort the democratisation process, because of their size $(100,000)$ and access to weapons and networks (Sawyer 2008:188; Nilsson 2008:192; Jennings 2007). In West Africa, in particular, ex-combatants have and continue to play a crucial role in the political development of the region. Ex-combatants also move across borders and can be recruited for other wars, especially if they have failed to create a viable life in their home country (see e.g. Nilsson 2008).

Since the informants for this study represent a wide range in terms of ethnicity, age, gender, military faction and reintegration program experience, useful insights can be obtained from this data. However, caution is required as the sampling process reminds us more of a snowball sample than anything else, and specific groups were targeted rather than a catch-all strategy. The goal of this paper is to present the similarities, the general traits they have in common, and present opposing or differing opinions when they were voiced by the participants. Given the nature of focus groups, this paper will not offer quantitative summaries of the opinions of the participants; rather it will map out the types of meanings attached to elections by excombatants in Liberia.

This paper also has methodological aims. The evaluation of electoral meaning is a way to gauge the appropriateness of applying focus groups to this field. Focus groups are still a rare tool in political science, and when applied, it is usually as a preamble for designing a survey. As a discipline political science is diverse in its methods (spanning both extremes of quantitative and qualitative work), yet focus groups have only of late become relevant to that discipline. This paper makes clear, that it is a data collection method valid on its own, for multiple reasons, but it will also highlight some of the difficulties involved with this method.

Starting with a brief theoretical overview of election related issues that shed light on the concept of electoral meaning and then moving on to a rather lengthy method section, this paper discusses the pros and cons of focus groups. The next section describes the findings visà-vis ex-combatants' election experiences. In the conclusion, the main findings, such as the lack of legitimacy and high degree of participation, are discussed and some reflections concerning the method choice are offered. 


\section{The Issue of Elections}

Clearly, elections are not the only scene where the political worldview of ex-combatants in Liberia can be observed. However, elections do provide a convenient starting point, both methodologically and theoretically. Methodologically, because it is an event that is easy to relate to for the participants, and theoretically because we cannot have democracy without elections, and election experiences are likely to shape individual experiences and their understanding of democracy. Indeed, elections are literally the main event where people practice their democratic citizenship.

\section{The Gateway to Democratic Citizenship}

As stated by Elklit, the experience and meaning attached to elections among the masses have bearing on the democratisation process: "Only when voters experience meaningful contestation and participation in the political process [...] will they develop some kind of normative commitment to democracy" although this is often forgotten in research on democratisation (1999:32; see also Akokpari and Azevedo 2007:75; Rustow 1970:344f). Others are more hesitant about the potential of elections in the democratisation process, especially in a post-conflict situation (Sawyer 2008:178). The purpose of my research is to examine these aspects, particularly as it relates to ex-combatants. In order to systematize the investigation of electoral meaning, I have opted to develop three points of assessment, namely the act of voting, the equality principle and the legitimacy of the elections.

Political behaviour in relation to elections becomes narrowly defined as those acts related to voting and election campaigns. Whether or not elections are seen as having the potential to change things, determines their perceived importance. In order to gauge their opinions regarding voting, pictures of the election in 2005 were used as a starting point for our discussions. How much weight is attached to this form of behaviour, and do they feel motivated to use this opportunity? Whether they voted is also relevant here, for if elections are not seen as a means to impact, clearly you are unlikely to feel motivated to use your vote. Depending on the motivation, voting may not even be an act of democracy. Some suggest that the meaning of voting in Africa remains tangled up with problematic ideas of representation and express communal links and potential material gains, rather than political preference (Chabal and Daloz 1999:39, 154; Schaffer:23, 88-89, 106-31). Finally, the degree of participation in elections, and how they feel about participating in the future are relevant here. Thus, voting will be studied as it relates to motivation and participation.

A second point of assessment is the equality principle. From the standpoint of the citizenry, equality is mainly about the right to vote. Is it seen as a right? Who should have it, and secondly how should this right be applied, one vote-one person? Thus, the aspect of equality relates to how access to voting is portioned out.

Finally, the legitimacy of the elections and the election results are important in order to understand what support the election process enjoys. Electoral victory does not guarantee the legitimacy of the results (Chabal and Daloz 1999:151), not even in free and fair elections as we shall see later. The elections also affect the legitimacy of democracy as a whole (Akokpari and Azevedo 2007:79), and Bratton highlights that contestation over this issue may pose problems for the consolidation of democracy $(1998: 53,63,66)$. Who is seen to own the process; did the right person win; did they win with legitimate means? 
Thus, to summarize, electoral meaning will be investigated as it relates to behavioural aspects (motivation and participation), the application of the equality principle regarding the vote, and the legitimacy of the elections.

\section{Methodology}

This paper relies on focus group interviews carried out with 16 groups, totalling 88 participants, among which 27 were female and 61 were male. The data collection was carried out between April $15^{\text {th }} 2008$ and June $15^{\text {th }} 2008$, in four areas of Liberia: Monrovia, Kahtoe Town, Foya and Zwedru, thereby covering both the rural and the urban parts, as well as inland (North and East) and coastal regions.

\section{Why focus groups?}

There are several reasons for this choice of data collection. The ontological reasons can be divided into two: the depth of human opinion and the autonomy of human opinion. Survey work and even individual interviews presuppose that all individuals have an opinion regarding all questions, and people may often feel forced into offering an opinion. In these cases we do not know if the opinions were offered because it was theirs, or because they felt like they ought to have a response (Holmberg and Petersson 1980:73f). This problem is alleviated in focus groups. The other aspect relates to whether opinions are independent of context, the autonomy of human opinion. Is the self independent of her context? If she was, then one "merely [has] to ask the right questions and the other's 'reality' will be revealed" (Gubrium and Holstein 2002:12), but to think that we are able in individual interviews to isolate the individual from the group is illusory, for one, we cannot completely eradicate the interviewer. The production of knowledge cannot be atomized in this fashion, even if we try. Indeed, as human opinion tends to be created in social contexts, using focus groups should increase the external validity of the study (Albrecht et al. 1993:54). And as it is reasonable to expect their network of ex-combatants to be salient for their political interaction, it makes sense to make use of focus groups to capture this aspect.

The more pragmatic reasons include the fact that focus groups give rise to two forms of knowledge: the content of the conversation and the interaction between participants (Eriksson 2006:44; see also Morgan 1997). The interaction itself is also one of the main advantages of focus groups in comparison to other qualitative forms of data collection, as the participants tend to compare and contrast their experiences and opinions, thereby increasing the explicitness of the data obtained (Morgan and Krueger 1993:16-17).

Secondly, in contexts where political freedoms are still new and politics has been conflictual, people tend to be more worried about exposing their political views to strangers (Holmberg and Petersson 1980:68); using focus groups may mediate this. Ex-combatants have often been described as a problematic group on whom to do research, as it can be hard to gain their trust and often they provide stories that fit with their preconceptions of why you are there as a researcher (see e.g. Nilsson 2008:55; Utas 2003; Utas and Christensen 2008). This seems to suggest that only lengthy participant observation would yield the data necessary. Clearly, participant observation could be useful, but this form of data collection is much more costly in terms of time and the topics of interest for this paper may be rarely discussed naturally. Focus groups are, however, known to be appropriate when working with marginalized groups and when you need a permissive method of data collection (Morgan and Krueger 1993:15, 18). While marginalisation in and of itself cannot explain combatant status, most ex-combatants belonged to the marginalized sections of societies before the war and seem to have fallen back 
into that after the war (Utas 2003:227-250; Bøås and Hatløy 2008:34). This also became apparent during the interviews, where the discussion would often revolve around their challenges with being located at the fringes of society. The participants in the focus groups also openly voiced their experience and feelings concerning issues that are usually seen as sensitive or precarious (e.g. vote buying). Compared to the individual interview setting, trust was established at a much faster rate, which in a post-conflict context is vital. The trust already established within the group of ex-combatants can in a sense be borrowed by the focus group, albeit not to the same extent as within a group entirely made out of excombatants.

Thirdly, their opinions are clearly exposed to a social desirability bias, both internally among themselves but also in relation to me, the interviewer, even if the influence of the interviewer, is somewhat downplayed by relative size of the group (Frey and Fontana 1993:26). But the filtering of their opinions does not render the data useless, rather the opposite. Such opinions are perceived by the ex-combatants as the norm, or the 'correct' answer, and thus reflect their social reality in a more accurate way.

Fourthly, the group context also creates a reliability test, as the groups were not aware of what questions would be discussed, hence they could not coordinate their answers in advance. Thus, the content of the conversation was subjected to a form of control, as the participants had the opportunity to object or present an alternative view if there was disagreement or deception on someone's part. Reliability is also increased through the inherent comparing and contrasting within and between the groups (Knodel 1993:50).

Focus groups are often believed to create conformity, which is refuted by focus group methodologists as this is mainly the case when these groups have to make decisions (Morgan and Krueger 1993:4-8). Some of the groups, however, did exhibit very uniform opinions, while some did not. This variation is, thus, more likely to be related to the participants themselves than the instrument used for data collection. Certain participants may value uniformity and consensus to a much higher degree than other participants. However, the group dynamic does colour the data obtained, which may sometimes silence certain participants. As the groups used also included participants that knew each other before participation, these relationships outside the group may also have tainted interaction and possibly dampened potential comments, as they were not uttered in complete anonymity.

For the above reasons it is important to pay attention to the group interaction displayed in each group. I would argue that different personas are visible through this type of data collection; the groups do not homogenize to such an extent as to render invisible differences in opinion or language use. However, as the main unit of analysis remains the group in each instance, determining the degree of consensus in the group on a certain issue can be difficult. Sometimes all participants would make their opinion known, but this was far from the rule. Thus a reference to a particular group number does not necessarily entail consensus, but rather that a majority of the participants expressed this sentiment. As the participants were not asked to indicate agreement with a show of hands, it can be difficult to attribute such sentiments to the entire group. However, the groups were continually encouraged to express dissent or differing experiences, and when such disagreement was manifested this is discussed in the text.

Some of the notable disadvantages of using focus groups in this field relate to the problem of representativeness and the range of questions that can be covered in such a data collection 
method (Morgan and Krueger 1993:9). In a survey you are able to cover a wider spectrum of questions, but the answers will not be as nuanced as those obtained from focus groups, nor will you be able to evaluate the strength of such opinions. The representativeness of the results obtained are clearly hampered by the use of a strategic sample, the presence of an attitude cannot be easily quantified and generalized. Focus groups map out the territory of opinions, and if significant group differences exist one can infer that such differences of opinions are likely to exist among those segments of the population as well.

\section{Selection}

The groups were recruited in different ways. In some cases I approached the ex-combatants through the elders of the village, those in charge of the program or trainers known to have participated in the program. In one case I also visited a training facility to speak directly to some of those currently enrolled. And finally, I worked with a veterans' organisation in Monrovia, and through their network contacted potential participants and invited them to come to a discussion.

Each group was constructed in order to make them as internally homogenous as possible with respect to reintegration program experience, ${ }^{2}$ gender, faction, ethnicity and locality. Program experience, gender and locality also represent the break characteristics, i.e. attributes that differ between the groups that we expect to matter for the issue under study (Knodel 1993:39). This is sometimes also referred to as segmentation (Morgan and Scannell 1998:6367; Tursunovic 2002:5). See appendix 1 for more details on group composition.

Self-selection is to some extent a problem, as the participants can choose not to take part. In some cases, recruitment was carried out just before the discussion started, which meant that it was only those readily available for the discussion that could participate, e.g. ex-combatants already working in the fields would not have been included. All participants were given monetary compensation for their time and to cover transportation costs, to the amount of five USD (varying slightly depending on transportation needs) in keeping with focus group praxis (Morgan 1997). Overall, it was never difficult to recruit participants.

\section{Doing the interviews}

Each discussion started with a discussion over the research aims, issues of confidentiality and academic independence over some light snacks and drinks. The average length of the discussions was an hour and 45 minutes, but ranged from one hour to three hours. The size of each group varied from four to seven, but most groups included six participants. At the end of each discussion, they were asked to fill in a short survey that mainly covered demographic issues.

All groups were exposed to the same opening questions, but follow-up questions varied depending on the discussion itself. Prompting included questions like: Could you give an example of what you mean? Why do you think that is? Does everyone agree? Are there any alternatives? Why do you say that? Sometimes the discussion had to be cut off, in order to cover all of the questions included.

The bulk of the discussion concerning elections was towards the end of each talk, and initiated through the presentation of images depicting the election in 2005. The pictures included people voting, standing in line and campaigns for both presidential candidates Ellen Johnson Sirleaf and George Weah. The use of pictures was motivated by two things, firstly it 
helps as a memory device to take participants back to the situation at hand, particularly as almost three years had passed since the elections, and as the pictures were neutral they also allowed participants to voice spontaneous thoughts and ideas in relation to the pictures. All of the groups found it quite useful to refer to the photographs when discussing the elections. This method of starting the discussion made it easier for the participants to gear the conversation towards aspects relating to the election that was of major importance to them first, allowing them to set the agenda.

In the groups carried out in the rural setting, language was more of a problem. All interviews were carried out in English, but in the four groups in Grand Gedeh, a translator was present. I would start the conversation in English, and when required, this would be translated into Krahn, and if a participant so wished they could express themselves in Krahn and the translator would then translate it back to English for me. The majority of the conversation was always carried out in English however. In the two groups in Lofa County, no such separate translator was present, but individuals in the group would help to explain words or questions in Kissi to those not as fluent in English as themselves.

The participants had no problem seeing me as disconnected from the government of Liberia, but often asked for help, especially in relation to the reintegration programs. This prompted explanations of my work not only before the interviews, but also at the end of the discussions to press my academic independence and clarify how my work could benefit them. This was equally common, no matter what my point of contact with them had been (NGO, program officers, veteran's organisation or government employee). There are clear dangers with this, especially in terms of the reliability concerning their descriptions of their program experiences, as it tends to emphasize their stories as victims (also see Utas 2003:49-55), although this is not at the focus of this paper.

\section{Electoral meaning among ex-combatants}

\section{Voting: motivation and participation}

It was the norm among all the participants to vote if you were able to. The ex-combatants do not seem to differ from the general population, regarding voter turnout; voting was carried out in large numbers. This claim is also supported by a survey carried out in Monrovia among excombatants, where as many as 80\% claimed to have voted (Bøås and Hatløy 2008:50).

Indeed, evidence from Afrobarometer data even suggest that ex-combatants voted to a greater degree than the general population (Afrobarometer 2008). In addition, several of the participants in the urban groups were either members of a party, or had aided in the campaigns (especially on the side of George Weah) $\left(9,10,11,12,15,16,17\right.$ and 18). ${ }^{3}$ There were three main reasons for voting: personal gains, community gains and the rights argument.

Vote buying, in the form of money, rice, or smaller local projects, has been common in Liberia for a long time, and was confirmed during the elections of 2005 (Sawyer 2008:195; Barr and Moor 2005). Motivation based on personal gains was judged very differently by the groups. In some $(3,11$ and 17) this behaviour was seen as reprehensive and one of the problems of politics in Liberia, whereas for other groups (1,2 and 4) the complaint was more about failed promises. Politicians would make promises in exchange for votes, leaving the excombatants feeling let down. This experience led them to question the honesty of all politicians. In other groups (4, 7 and 9), participants expressed experience with vote buying but without evaluating the event positively or negatively, whereas in other groups some participants wanted to be paid in the future (16 and 18). One caveat is, however, in order here, 
professed norms or expectations of future behaviour does not necessarily entail actual adherence in the future (see e.g. Utas and Christensen 2008). This paper does not purport to predict future behaviour, but rather describe current reasoning and norms among excombatants in Liberia, which ought to provide a reasonable starting point.

Those that were motivated by community gains $(3,4,10,11,12,15,16$ and 17) often mentioned development (trade, investors, and work opportunities) and peace or for the price of rice to come down. ${ }^{4}$ Often the need to get a good leader was cited as the main reason why they voted $(3,8,9,10,11,13,14$ and 16). Some groups also mentioned the idea that voting and the election, as such, helps unite the country and create understanding (7,9 and 13). A few also expressed the more explicit argument of representation, that voting was about selecting those that could represent your interests, or the interests of the people $(7,12,14$ and 15), or at least those that could advance your interests the most: "but I think about my future plan. [...] I only think what... who will be usually best for me. You know, yeah. That I'll vote for. Not because you... what you give me, I will vote for you" (Bill, ${ }^{5} 3$ ).

Others also made the argument that it was their right to vote according to the constitution hence they felt motivated to exercise it. Not using your vote meant that you were giving up your say in the process, which could be detrimental both to the voter herself, but also the specific candidates and for the overall result $(8,9,12,14,16,17$ and 18).

Several mentioned that elections had the potential to change things, although some also stated that elections can bring both good and bad things and the outcome depended upon the character of those elected (Bart, 3). Interestingly, while most agreed that elections were useful, it was never at the top of the list when the participants discussed various forms of political participation. ${ }^{6}$ In terms of whether they wanted to vote again in the future, most participants answered in the affirmative: "We still want development. - We vote for development" (Bethany and Barbra, 4). Thus, the issues that motivated them in the last election remain relevant for their motivation in the next election, with some exceptions ( 2 and John, 9). The others in group 9 argued for future participation, as it was the only way to "make the country straight." Very few were explicit about using their vote to punish politicians who had failed them during the previous mandate (creating accountability) $(7,14$ and 17).

\section{Equality: the right to vote}

This area probably provides the most surprising and positive results concerning democratic attitudes among ex-combatants in Liberia. Issues of ethnicity and citizenship have been polarized and problematic for a long time in Liberia, particularly in relation to the Mandingos. ${ }^{7}$ Although questions of ethnicity cannot explain the war or faction composition, the issue of Liberian identity was at the heart of the war (Bøås and Hatløy 2008:37, 41, 47). During the elections of 2005, the issue of Mandingo citizenship and access to voting was a contentious one (Akokpari and Azevedo 2007:86; ICG 2005:3, 19; Sawyer 2008:194; Harris 2006:380).

Most of the participants were adamant about an inclusive demos (the group of people that make up the polity that constitutes a democracy), which included Mandingos. While I tried to encourage dissenting voices, one might still suspect that inclusion was a product of the interview context, and a wish to conform to what they thought was sought for. But if this was the case, the data still speaks to an interesting finding, namely they perceive an inclusive demos as the norm, as the 'correct' answer. Most groups were in favour of extending the right 
to vote to Mandingos (2, 3, 4, 7, 8, 9, 11, 12, 13, 14, 15, 16, 17 and 18). However not all participants extended the right to vote to Mandingos, and this usually created some discussion, where defenders of an inclusive demos were often the most vocal and expressive. This highlights the usefulness of focus groups; it allows us to gauge the strength of opinions, but it also shows how some individuals may be silenced in focus groups. Thus, although not universal, there is reason to be optimistic given the extent of this polarisation in Liberia in the past. $^{8}$

The right to vote was linked to the issue of citizenship, i.e. no citizenship - no right to vote (4, $7,8,9,10,13,14,15,16,17$ and 18). It did not matter whether such individuals were totally disinterested and ignorant about politics, if they could claim citizenship the groups were steadfast in their extension of the right to vote to such individuals. Group 9 was however an exception to this, as they felt that only those that knew what they were voting for should be allowed to vote.

The right to vote was often seen as a legal concept, as something regulated through law and the constitution. When asked to defend the reason for why only people 18 years old or older should be allowed to vote, only such legal claims were invoked and they would only on occasion offer a substantive argument for why such delineations made sense. For instance, Yona (13) claimed that at 18 you have enough experience to know what is good and what is bad, similar thoughts were also expressed by others (14 and 15). Thus, being a Liberian citizen and adult (18 or more) were the two basic requirements for access to the vote $(8,9,10$, $11,12,13,14,15,16,17$ and 18). One exception was Archie (15) who felt anyone no matter what age should have the right to vote, as it is the younger ones' future that is at stake.

The groups were also very forthright about the equality of the vote; among those with the right to vote, the idea that each person should only be allowed one vote was very much engrained in the participants. Playing the devil's advocate I tried to suggest that more educated people for instance should be given more votes, based on their knowledge and experience, an argument they did not buy into, but argued against (2, 3, 4, 13, 14, 16 and 18).

\section{Legitimacy: election results}

The issue of legitimacy plays into elections in several ways: the rules of the game, long-term legitimacy, fulfilment of election promises and contested election results. Concerning the rules of the game, several of the participants agree with the notion of majority rule $(1,3,10$, 12, 17 and 18). Some even described this as a local tradition, as something inherently Liberian to abide by results in this manner (Bishop, 12). Several of them also recognized that if you do not win this particular election, there is always the next election that you can turn to $(3,4,7$, and 18); this must be seen as evidence of trust in the long term process. There were other positive appraisals of the elections as well, which point to the legitimacy of the elections, for instance some participants expressed a sense of pride in the elections $(11,13,14$ and 17). Others described the elections as free and fair, a first for Liberia (12 and 18).

Shortly after the election, ex-combatants have been noted to have high hopes for the impact of the election, as many as $85.0 \%$ believed that the election would be followed by positive changes (Bøås and Hatløy 2008:50). However, three years later a fair amount of the participants felt disappointed by the elections. Clearly, there are both advantages and disadvantages with data collection occurring three years after the event of interest, but the excombatants would not have been able to reflect upon and place the elections in perspective without this passage of time. Their disappointment was related to unfulfilled expectations, 
either in the form of campaign promises not carried out, or a more general disappointment linked to the behaviour of politicians after the elections. The participants often mentioned a feeling of abandonment after the elections; politicians stopped listening or interacting with the electorate, creating the feeling that democracy only happens during elections $(1,2,3,4,7,9$, 11, 13, 14, 16, 17 and 18): "Yeah, the elections, you know, I feel good. But, what I want... for the government to do I can't see them do it. So now I am feeling bad again" (Brandon, 3). This disappointment was also related to politicians overstating what they would do once elected, and their tendency to become corrupt once in office.

In several of the groups the issue of the presidential elections and Weah's loss did put into question the legitimacy of the elections as a whole. A lot of the participants did not understand why a run-off election was organized; their line of argument was that Weah got the most votes, ${ }^{9}$ so he won the first round; hence, there was no need for a second run (18). Thus, in part, the idea of run-off elections seemed to several as staged by those who wanted a different result $(9,10,15$, and 16$)$. Some were very clear about who they suspected of cheating, namely the international community, the Americans $(10)$, or the NEC $(9,10,17)$. Others were vaguer, but had doubts about whether the will of the people was accurately reflected in the election results (Kasper, 11). Most of those that questioned the result of the election had also been active in the election campaigns on the side of Weah.

Several statements made by the Weah campaign, such as Weah winning the first round with $62 \%$ of the votes, or claims that he could only be defeated through massive cheating engineered by the US (Harris 2006:390; NDI 2007:24), have certainly contributed to the current perceptions among his supporters and ex-combatants. What is important to note is that almost three years later this suspicion still lives on. The longevity of their suspicion seriously decreases the legitimacy of the elections and could potentially have detrimental effects on the overall democratisation process. Indeed, some even felt less motivated to participate next time as a result of these issues (10).

In comparison to the general sentiment among several of the ex-combatants that Weah was cheated out of the election, in reality several things may have worked in favour of Weah rather than Johnson Sirleaf (Sawyer 2008:185-187; IRI 2006:13; Harris 2006:384-388; NDI 2007:20-22). However, it has been harder to validate or repudiate the idea that the international community had decided on Johnson Sirleaf. There were no blatant moves in favour of Johnson Sirleaf, but it is impossible to determine whether Johnson Sirleaf had an advantage in terms of resources and an implicit support from the West (Harris 2006:378-90; NDI 2007:14f; IRI 2006: 10).

\section{Conclusion}

This paper has taken stock of the emerging democratic culture among ex-combatants in Liberia, through an analysis of their personal experiences of the elections of 2005. An election generally considered such a success has failed to produce unconditionally positive results with respect to the general electorate. This highlights the importance of taking into consideration the experience of the masses when exploring the importance of an election in the democratisation process. If we are to evaluate an election, international observations are important, but in terms of the consolidation of democracy, the experience of the voters themselves is fundamental as this analysis of the ex-combatants' experience shows. 
Participation seems to be the norm, and there is critique against vote buying. Given Liberia's long history of vote buying, the presence of such criticism is noteworthy. In terms of applying the principle of equality, ex-combatants are living up to such ideals, although there are exceptions relating to the inclusion of Mandingos. Most extended the right to vote to Mandingos, as long as they could claim Liberian citizenship. Some of the ex-combatants are clearly aspiring higher ideals, particularly vis-à-vis motivation for voting. The notion of vote buying as something reprehensive and the notion of representation, and of 'one person - one vote', are part of the electoral political culture of ex-combatants. This is noteworthy, particularly in the face of the otherwise weak political institutions in Liberia.

The most notable problem of the elections relate to the issue of legitimacy, i.e. the lack of trust in the results and the feeling of abandonment after the elections, which have bearing on the further deepening of democracy in Liberia. Firstly, the perception of the legitimacy of the elections, partly a result of Weah's behaviour, is a serious problem for the consolidation of democracy, particularly as the protests did turn violent and some of the slogans used during these protests - 'No Weah, No Peace' - seem to suggest other means of change than the constitutional arrangement (Deutsche Presse-Agentur 2005-11-11). Contestation over election results stands in the way of consolidation; the legitimacy of the system, as such, is questioned, and democracy may not be the only game in town.

Secondly, for some, it appears democracy only happens on Election Day, in light of consolidation this is not a positive result either; ideally the empirical experience of democracy should extend beyond elections. The feeling of abandonment, failed election promises and a feeling of remoteness and distrust towards politicians, although not mentioned by all the groups, were very pervasive. In relation to this, it is interesting to note that the political climate for discussing and criticizing changes around elections, at this time it is more permissible to express dissent, something which is less tolerated in between elections. ${ }^{10}$ This highlights the exceptional character of the election period, as a time when politicians engage with their citizens and when open discussion is accepted. In contrast, the ensuing feeling of alienation to politics may be very detrimental to ongoing processes of democratisation and peacebuilding.

While in this paper, the use of focus groups has mainly allowed a deeper understanding of the ex-combatants' electoral experience, the method of segmentation facilitates venturing into the domain of explaining to some degree. So, what conclusions can be drawn concerning differences within the ex-combatant community? While these break characteristics can be used to draw such conclusions, it is a difficult and not always clear-cut enterprise. As there were differences between the groups - some were more refined $(3,12,13,14,17$ and 18) and some were less politically refined (1, 2, 4 and 10) - it should be possible to utilize these differences to consider what may have determined them. For example, distrust concerning the election results was more evident among the urban groups, possibly this could be connected to a closeness to politics in general and active involvement in campaigning (Weah supporters). If we compare male and female groups with the same characteristics, it does not seem as if gender matters. The more educated groups were often more expressive, but did nonetheless exhibit a lack of trust in the election results. Although groups in the rural parts of Liberia were often less politically aware, this was not an absolute rule (notably group 3). Differences in factional membership and ethnicity do not seem to be determinants of their electoral experience in this particular instance. 
Due to limitations of space a deeper involvement with the details of the talk produced in the focus groups was not possible in this paper, but has been carried out more in full elsewhere (Söderström 2009). One of the advantages of focus groups is the rich material produced by them, but this also represents one of the main challenges - how do you present data produced in focus groups in a way that keeps their contextual richness intact and yet also presents essential findings with a clear analytical voice? Clearly, this is a challenge which will continue to haunt us as the article format for disseminating research continues to dominate.

One aspect that became a clear advantage of focus groups, particularly within the postconflict context, is the creation of trust within the group. Focus groups allow the participants more control over the discussion, partly this relates to sheer numbers, but it can also be augmented through a less intrusive moderator. Other focus group challenges relate to ascribing an opinion to the individual or the entire group. Each individual is situated within a group, a group which may either silence or trigger his expression, thus the group remains the main unit of analysis, although some individual data is available. For this reason, I have opted to only report the group number in relation to an expressed opinion, and only indicate a specific person when quoting or when it was clearly just the opinion of one person. In this enterprise, it is usually impossible to determine whether this entails consensus, a majority or simply the voice of the vocal. The only remedy possible here, is to, during the focus groups, continually encourage disagreement. Finally, another problem when reporting focus group data is the issue of missing values. Not all issues were discussed in every group, thus it is quite possible that had one group been confronted with statements of another group, they may have voiced either agreement or disagreement, we simply cannot know which. All of these issues highlight the non-quantitative character of focus groups; focus groups deal well with mapping different typologies of meaning and experiences and less well with exhaustive lists of who felt or thought what.

\section{References}

Afrobarometer. 2008. "Liberia Survey Data: Round 4". Michigan State University, Department of Political Science.

Akokpari, J., and Elisabete A. 2007. Post-Conflict Elections in Africa: Liberia and GuineaBissau in Comparative Perspective.African Journal of International Affairs, 10(1 \& 2): 73-92.

Albrecht, T., Johnson, G. and Walther, J. 1993. Understanding Communication Processes in Focus Groups. InSuccessful Focus Groups: Advancing the State of the Art, ed. D. L. Morgan. Newbury Park: Sage Publications.

Barr, A. and Moor, J. Liberia Elections: Read Pre-Election Statement, Election Watch Reports. [on-line]. The Carter Center, 2005. Available at:

http://www.cartercenter.org/news/documents/doc2184.html?printerFriendly=true (accessed 25 June 2008).

Bratton, M. 1998. Second Elections in Africa. Journal of Democracy, 9(3): 51-66.

Bøås, M. and Hatløy, A. 2008. 'Getting in, getting out': militia membership and prospects for re-integration in post-war Liberia.Journal of Modern African Studies 46(1): 33-55.

Chabal, P. and Daloz, J.P. 1999. Africa Works: Disorder as Political Instrument. Edited by A. 
de Waal and S. Ellis. Oxford: The International African Institute, James Currey \& Indiana University Press.

Deutsche Presse-Agentur. Liberian riot police disperse demonstrators with teargas. [on-line]. Monsters and Critics, 2005-11-11. Available at:

http://www.monsterandcritics.com/news/africa/news/printer_1061551.php (accessed 27 January 2009).

Elklit, J. 1999. Electoral institutional change and democratization: You can lead a horse to water, but you can't make it drink.Democratization, 6(4): 28-51.

Elklit, J. and Svensson, P. 1997. What Makes Elections Free and Fair? The Rise of Election Monitoring. Journal of Democracy,8(3): 32-46.

Eriksson, C. 2006. "Det borde vara att folket bestämmer" En studie av ungdomars föreställningar om demokrati, Political Science, Örebro University, Örebro.

Frey, J. and Fontana, A. 1993. The Group Interview in Social Research. In Successful Focus Groups: Advancing the State of the Art, ed. D. L. Morgan. Newbury Park: Sage Publications.

Gubrium, J. and Holstein, J. 2002. From the Individual Interview to the Interview Society. In Handbook of Interview Research: Context \& Method, ed. J. F. Gubrium and J. A. Holstein. Thousand Oaks: Sage Publications.

Harris, D. 2006. Liberia 2005: an unusual African post-conflict election. Journal of Modern African Studies, 44(3): 375-395.

Holmberg, S. and Petersson, O. 1980. Den magiska felmarginalen. In Inom felmarginalen: En bok om politiska opinionsundersökningar. Stockholm: Liber förlag.

ICG. 2005. "Liberia's Elections: Necessary but not Sufficient." In Africa Report. Dakar/Brussels: International Crisis Group.

IRI. 2006. "Election Observation Mission Final Report." Washington: The International Republican Institute.

Jennings, K. 2007. The Struggle to Satisfy: DDR Through the Eyes of Ex-combatants in Liberia. International Peacekeeping, 14(2): 204-218.

Knodel, J. 1993. Design and Analysis of Focus Group Studies: A Practical Approach. In Successful Focus Groups: Advancing the State of the Art, ed. D. L. Morgan. Newbury Park: Sage Publications.

Lindberg, Staffan I, ed. 2009. Democratization by Elections: A New Mode of Transition. Baltimore: Johns Hopkins University Press.

Linz, J. and Stepan, A. 1996. Toward Consolidated Democracies. Journal of Democracy, 7(2): 14-33.

Mainwaring, S. 1992. Transitions to Democracy and Democratic Consolidation: Theoretical 
and Comparative Issues. In Issues in Democratic Consolidation: The New South American Democracies in Comparative Perspectives, ed. S. Mainwaring, G. O'Donnell and J. S. Valenzuela. Notre Dame: University of Notre Dame Press.

Morgan, D. 1997. Focus Groups as Qualitative Research. 2nd ed. Thousands Oaks: Sage Publications.

Morgan, D. and Scannell, A. 1998. Focus group kit. Vol. 2, Planning focus groups. Thousand Oaks: Sage Publications.

Morgan, D. and Krueger, R. 1993. When to Use Focus Groups and Why. In Successful Focus Groups: Advancing the State of the Art, ed. D. L. Morgan. Newbury Park: Sage Publications. NDI. 2007. "Observing Presidential and Legislative Elections in Liberia." The National Democratic Institute and the Carter Center.

Nilsson, R. 2008. Dangerous Liaisons. Why Ex-Combatants Return to Violence - Cases from the Republic of Congo and Sierra Leone, Department of Peace and Conflict Research, Uppsala University, Uppsala.

Rustow, D. 1970. Transitions to Democracy: Toward a Dynamic Model. Comparative Politics, 2(3): 337-63.

Sawyer, A. 2008. Emerging Patterns in Liberia's Post-Conflict Politics: Observations from the 2005 Elections. African Affairs, 107(427): 177-199.

Schaffer, F. 1998. Democracy in Translation: understanding politics in an unfamiliar culture. Ithaca \& London: Cornell University Press.

Schedler, A. 1998. What is Democratic Consolidation? Journal of Democracy 9(2): 91-107.

Schmitter, P. and Karl, T. 1991. What democracy is... and is not. Journal of Democracy, 2(3): $75-88$.

Soderstrom, J. 2009. Valerfarenheter bland f.d. kombattanter: En ny syn på demokrati i Liberia? Politica, 41(3): 300-314.

Thomas, Kate. Liberians drop rice for spaghetti. [on-line]. BBC News 2008-04-22. Available at: http://news.bbc.co.uk/go/pr/fr/-/2/hi/africa/7360649.stm (accessed 16 July 2008).

Tursunovic, M. 2002. Fokusgruppsintervjuer i teori och praktik. Sociologisk Forskning 39(1): $1-30$.

Utas, Mats. 2003. Sweet Battlefields. Youth and the Liberian Civil War, Cultural Anthropology, Uppsala University, Uppsala.

Utas, M. and Christensen, M. 2008. Mercenaries of democracy: The 'Politricks' of remobilized combatants in the 2007 general elections, Sierra Leone. African Affairs, 107(429):515-539. 
Young, Tom. 1993. Elections and Electoral Politics in Africa. Africa: Journal of the International African Institute, 63(3):299-312.

\section{Acknowledgements}

I would like to thank the following people for helpful comments on this paper: Gina Gustavsson, Sten Widmalm, Mats Utas, Li Bennich-Björkman, Anna Jarstad and David Collier. I would also like to thank the Nordic Africa Institute, the Department for Research Cooperation (SAREC) at the Swedish International Development Cooperation Agency and Rektors resebidrag från Wallenbergs Stiftelse who through their generous grants enabled the field work.

\section{About the Author}

Johanna Söderström is currently completing her $\mathrm{Ph} . \mathrm{D}$. in political science at the Uppsala University (Department of Government). Her research deals with the interface between democratisation and peacebuilding, in particular how the political reintegration of excombatants in Liberia is affected by the participation in demobilisation, disarmament and reintegration programs. She can be contacted at johanna.soderstrom(AT)statsvet.uu.se.

\section{Endnotes}

${ }^{1}$ While terms such as these have undergone conceptual stretching and are difficult to apply uniformly, in this context they are meant to imply that the elections were free from coercion and were conducted with impartiality (for a longer discussion of this see Elklit and Svensson 1997:32-43).

${ }^{2}$ The training programs included in the sample are Young Men Christian Association (YMCA), Monrovia Vocational Training Center (MVTC), the United Methodist Committee on Relief (UMCOR) and German Agro Action (GAA). The other groups where either involved in formal education or no program at all.

${ }^{3}$ The numbers within parentheses refer to the focus group number, which are also listed in Appendix 1.

${ }^{4}$ Rice has always been a political issue in Liberia. The country has never been self-sufficient in rice production, although it is the main staple food. In 1979 the rice riots in Monrovia was the result of government intention to increase the price of rice, and some claim that this event set Liberia on the path toward war. The price of rice has continually been increasing over the past decades, and in April of this year $50 \mathrm{~kg}$ of rice cost $34 \mathrm{USD}$, compared to half that amount just six months prior (Thomas 2008-04-22).

${ }^{5}$ The names used are not the real names of the participants. Participants within the same group have names starting with the same letter.

${ }^{6}$ Other forms of political participation and the reasoning behind such choices are the topic for an entire chapter in my forthcoming dissertation.

${ }^{7}$ The ethnic group of Mandingos settled later than other groups in Liberia, but they were present when the American Colonization Society landed in Liberia and created the Liberian state. They do not have a majority in any of the counties in Liberia, and are often seen as different partly because of religious issues (they are more often Muslim than Christian), but also because of business acumen.

${ }^{8}$ The issue of defining the demos in Liberia is a topic for an entire chapter in my forthcoming dissertation. 
${ }^{9}$ Weah received $28.3 \%$ of the votes and Johnson Sirleaf $19.8 \%$ of the votes in the first round.

${ }^{10}$ The issue of tolerance and dissent are the topics of another chapter in my forthcoming dissertation.

\section{Appendix 1: Focus Group Composition Overview}

\begin{tabular}{|l|l|l|l|l|l|l|l|}
\hline No & Program & Area & Gender & Faction & Ethnicity & Size & $\begin{array}{l}\text { Average } \\
\text { Age }\end{array}$ \\
\hline 1 & GAA & Rural & Male & MODEL & Krahn & 7 & $25-30^{*}$ \\
\hline 2 & GAA & Rural & Female & MODEL & Krahn & 5 & ${\text { over } 35^{*}}^{*}$ \\
\hline 3 & GAA & Rural & Male & MODEL & Krahn & 4 & $25-30(27)^{\star}$ \\
\hline 4 & GAA & Rural & Female & MODEL & Krahn & 6 & $20-25^{\star}$ \\
\hline $5^{\star *}$ & MVTC & Urban & Male & - & mixed & 5 & $30-35^{*}$ \\
\hline $6^{\star *}$ & Various & Urban & Male/femal & mixed & mixed & 6 & ${\text { over } 35^{*}}^{*}$ \\
\hline 7 & UMCOR & Rural & Male & Mixed & Kissi & 4 & 19.5 \\
\hline 8 & UMCOR & Rural & Female & GOL & Kissi & 4 & 17.5 \\
\hline 9 & MVTC & Urban & Male & GOL & Bassa/Kpell & 6 & 33 \\
\hline 10 & MVTC & Urban & Male & LURD ${ }^{* * *}$ & Bassa** & 6 & 29.7 \\
\hline 11 & None & Rural & Male & GOL/LURD & Kpelle & 5 & 35.4 \\
\hline 12 & YMCA & Urban & Male & LURD/GOL & Mixed & 6 & 20 \\
\hline 13 & YMCA & Urban & Female & GOL & mixed & 6 & 31.5 \\
\hline 14 & None & Urban & Male & GOL & Loma & 6 & 23.2 \\
\hline 15 & YMCA & Urban & Male & MODEL & Kpelle*** & 6 & 27.8 \\
\hline 16 & MVTC & Urban & Male & MODEL & Mixed & 6 & 30.6 \\
\hline 17 & University & Urban & Male & GOL & Mixed & 5 & 29.5 \\
\hline 18 & High & Urban & Female & GOL & Gio** & 6 & 30.5 \\
\hline
\end{tabular}

${ }^{*}$ Exact age not given for participants, based on age category (median). If several also gave an exact age, mean in parentheses.

** Indicates that the group was not included in this analysis. Both groups are points of reference, rather than main objects of study.

*** Indicates that the group consisted mainly of such individuals, but not exclusively. 